Indian J. Anim. HIth. (2019), 58(2) -Special Issue: 39-52

DOI: https://doi.org/10.36062/ijah.58.2SPL.2019.39-52

Review Article

\title{
EMERGENCE AND SPREAD OF ANTIMICROBIAL RESISTANCE IN MOTILE AEROMONADS OF THE AQUACULTURE ENVIRONMENT
}

\author{
T. JAWAHAR ABRAHAM* AND A. BARDHAN \\ Department of Aquatic Animal Health, Faculty of Fishery Sciences \\ West Bengal University of Animal and Fishery Sciences \\ Chakgaria, Kolkata-700 094, West Bengal, India
}

\begin{abstract}
The global rise in antimicrobial resistance (AMR) among bacteria causing infectious diseases and the associated risks on human health are well known. The uproar of AMR has provided with the most severe health threat of the century. The research on the AMR of the organisms present in the environment is, however, meagre. The bacterial species of the genus Aeromonas is widely distributed in the environment that comprises both motile and non-motile variants. Several of them are autochthonous to the aquatic environment. The motile aeromonads, in particular, are notorious and contribute to severe health hazards to the humans and aquatic animals. In a variety of fish, they cause motile Aeromonas septicemia (MAS). Immunosuppressive events like nutritional, environmental and handling stress may trigger MAS. Different groups of antibiotics are used in the treatment of human and animal diseases and the indiscriminate use of which leads to disturbing consequences of AMR. Much of the susceptibility information available on the genus Aeromonas are based solely upon three major species associated with human diseases. It is not entirely clear whether those patterns can be extrapolated to other less frequently encountered taxa causing illness. In recent years, the emergence of AMR among the motile aeromonads of fish demonstrated the abuse of antibiotics in aquaculture. In this review, the AMR among motile aeromonads of the aquaculture environment and their mitigation are discussed. The available data indicated that the opportunistic pathogens like motile aeromonads might serve as important vectors of AMR in the aquatic environment.
\end{abstract}

Key words: Antibiotic-resistant genes, Antimicrobial-resistance, Aquaculture, Motile aeromonads, Motile Aeromonas septicaemia

Aeromonads are ubiquitous and autochthonous to the aquatic environment. The oldest and first report of an organism resembling Aeromonas was made by Zimmerman (1890) at Chemnitz (Germany), who coined the name Bacillus punctatus due to its nature of colonies on gelatin plates. The genus Aeromonas formally accepted and published in the $7^{\text {th }}$ edition of Bergey's Manual of Determinative Bacteriology, have

*Corresponding Author 
a complex taxonomy and is divided into two major groups namely motile group comprised of over 30 species and a nonmotile group comprising a singular species A. salmonicida (Graf, 2015). The motile representatives of the genus Aeromonas have been in a state of constant flux through the continuous introduction of new phenotypic and genotypic data. As a consequence, the taxonomic history of motile aeromonads has been one of confusion and controversy, that led to several reclassifications (Janda and Abbott, 2010; Beaz-Hidalgo et al., 2013; Graf, 2015).

Motile aeromonads are widely distributed in the aquatic environment throughout the world and their autochthonous presence among freshwater, marine and brackishwater (estuarine) environments suggested their popularity as the indigenous microflora of fish (Janda and Abbott, 2010). As large numbers of species are being identified and classified among the motile aeromonads group, the advent of modern taxonomic methods may question the reliability of earlier identifications (Graf, 2015). It is of noteworthy that some names that have been proposed are still not universally accepted (Rasmussen-Ivey et al., 2016; Králová et al., 2016). Multiple research studies have been done employing 16S rRNA gene sequence analysis of the genus Aeromonas, which elucidated that the members of this genus form a distinct line within GammaProteobacteria. This genus is comprised of mesophiles and psychrophiles, which can cause a number of diseases to warm and cold-blooded animals (Graf,2015). Aeromonas can cause extra-intestinal diseases in humans, especially in immunocompromised individuals, including septicemia, wound infections, urinary tract infections, hepatobiliary tract infections and necrotizing fasciitis (Janda and Abbott, 2010). This report discusses the role of motile aeromonads as a pathogen of fish in aquaculture, the emergence of AMR in the aquaculture environment and their mitigation.

\section{Motile Aeromonas septicaemia (MAS) in aquaculture}

The MAS has been known by several names like Aeromonas infection, motile aeromonad infection (MAI), haemorrhagic septicemia, red sore and infectious abdominal dropsy (Öztürk and Altinok, 2014). The first report of MAS was by Schäperclaus (1930) in carps and subsequently, the works of several authors on motile aeromonads have been amply reviewed (Graf, 2015; Austin and Austin, 2016; Plumb, 2018). Also, the epizootiology of MAS has been studied vastly and reviewed by Janda and Abbott (2010). These species can associate themselves with algae, biofilms and zooplankton. They are indigenous to the gut microflora of many vertebrates and invertebrates and have the potential to harbour and spread motile aeromonads (Janda and Abbott, 2010). The uptake of these pathogenic motile aeromonads is mainly by dermal and oral routes, with the former occurring after disruption of the fishes' first line of mucosal defences. Asymptomatic carriers are more likely to deposit the bacterium in their faeces, which accumulate among the benthic flora (Stratev et al., 2015). Diseased individuals may shed these bacteria from open lesions and are preyed upon by other fish (Janda and Abbott, 2010). 
The MAS can be correlated to many predisposing factors such as injury, infection with different aetiological agents, or immunosuppressive events like nutritional, environmental and handling stress. Besides, the MAS is often a complicating factor in columnaris disease, saprolegniosis and several cases of viral aetiology (Austin and Austin, 2016). Aeromonas hydrophila, A. sobria, A. caviae, A. schubertii (Öztürk and Altinok, 2014) and possibly other motile aeromonads are capable of producing diseases in fish (Hanson et al., 2014; Plumb, 2018). Typical MAS outbreaks are most prevalent in spring and fall when fluctuating temperatures compromise the immune system (Hanson et al., 2014). The external symptoms of MAS range from abscesses and ulcers to accumulation of fluid in scale pockets (lepidorthosis) and abdomen. Internal symptoms include blood in ascites and swollen friable kidney (Stratev and Odeyemi, 2017). Control measures for an Aeromonas epidemic must, therefore, address both environmental and bacteriarelated constituents. Reducing stress is both challenging and vital to Aeromonas control (Austin and Austin, 2016; Plumb, 2018). The rapid increase in water temperature and avoidance of pathogens, diseased fish introduction and contaminated water are suggested (Stratev and Odeyemi, 2017; Plumb, 2018). Prophylactic antibiotics have been recommended following known stress, but this approach can increase the incidence of antibiotic resistance, and the cost may be prohibitive (Plumb, 2018).

Table 1. The dose and dosage of antibiotics used against MAS in fish

\begin{tabular}{lll}
\hline Antibiotic/Class & \multicolumn{1}{c}{ Dose and dosage } & References \\
\hline Oxytetracycline & $\begin{array}{l}2.5-3.75 \mathrm{~g} / 100 \text { pound fish/ } \\
\text { day for } 10 \text { days }\end{array}$ & USFWS, 2015
\end{tabular}

Furanace (Nifupirinol)* $\quad$ Immersion treatment with 1-2 Austin and Austin, 2016 ppm for $5-10 \mathrm{~min}$ in water

Ormethoprim and $50 \mathrm{mg} / \mathrm{kg}$ fish/day for 5 days $\quad$ USFWS, 2015 sulfadimethoxine

*: Currently unapproved for aquaculture use

Table 2. The resistance and susceptibility of motile aeromonads' towards various antibiotics Susceptible Aminoglycosides, carbapenems, cephalosporins (extended-spectrum), (90-100\%) cephalosporins ("fourth generation"), macrolide (azithromycin), monobactams, nitrofurans, penicillin (extended-spectrum), phenicols, quinolones, tetracyclines Intermediate Aminoglycosides, antifolates, cephalosporins (expanded spectrum) (70-90\%) Resistant $(<70 \%)$ Antifolates, cephalosporins (narrow spectrum), penicillins (extended spectrum), macrolides, penicillins (narrow spectrum)

(Source: Janda and Abbott, 2010) 


\section{Antibiotic usage against motile Aeromonas septicaemia}

Disease control in aquaculture relies on an amalgamation of good management practices, the use of few approved and commercially available drugs and vaccines, and prevention of infection (Austin and Austin, 2016). In aquaculture, the use of antimicrobial compounds essentially started with the work of Gutsell (1946), who recognized the potential of sulphonamides for combating furunculosis in trout. A range of antimicrobial compounds in aquaculture rapidly expanded following the introduction of sulphonamides (Austin and Austin, 2016). The detailed descriptions of the antibiotics that are used against MAS in fish are presented in Table 1. Drug choices for the treatment of common infectious diseases have become progressively restricted. To date, only three antimicrobials are approved by the United States Food and Drug Administration (USFDA) as feed additives for the treatment of bacterial disease in fish, which has been recognized worldwide as food additives used for the treatment of bacterial infection in fish (USFWS, 2015). It includes (i) oxytetracycline (Terramycin $\AA$ 200), (ii) florfenicol (Aquaflor $\AA$ ) and (iii) ormethoprim and sulfadimethoxine (Romet30). The use of unapproved drugs or misuse of approved drugs in aquacultured fish poses a potential human health hazard. These substances may be toxic, allergenic, or carcinogenic, and/or may cause antibioticresistance in pathogens that affect humans (Leonard et al., 2015).

\section{Antimicrobial resistance in motile aeromonads}

The general view of aquacultured motile aeromonads' resistance and susceptibility towards various antibiotics as classified by Janda and Abbott (2010) are presented in
Table 2. Aeromonas spp. are intrinsically resistant to ampicillin and cefazolin due to their beta-lactamase production (Dias et al., 2012). Most aeromonads continue to be susceptible to tetracyclines, aminoglycosides, quinolones, trimethoprim-sulfamethoxazole and third-generation cephalosporins (Janda and Abbott, 2010). In recent years, increasing resistance references to tetracyclines, trimethoprim-sulfamethoxazole, some extended-spectrum cephalosporins (ceftriaxone, cefotaxime and cefixime) are emerging (Piotrowska and Popowska, 2014, 2015; Deng et al., 2016; Zhou et al., 2019). In clinical biology, the overall susceptibility profile for the genus Aeromonas does not appear to have changed appreciably from what was recorded in studies conducted between the mid-1980s and mid1990s (Stratev and Odeyemi, 2016). Fluoroquinolone resistance among Aeromonas isolates remained uncommon, and occur in $<10 \%$ of the motile aeromonads (Aravena-Roman et al., 2012). An increasing ciprofloxacin-resistance rate was, however, noted in Aeromonas isolates associated with intra-abdominal infections in the Asia-Pacific region, from $7.8 \%$ between 2003 and 2006 to $16.6 \%$ between 2007 and 2010 (Li et al., 2012). Aminoglycoside resistance remains rare worldwide (Kimura et al., 2013). Overall, in addition to well-known chromosomally encoded beta-lactamases, aeromonads would acquire plasmids or integron-mediated resistance genes, expressing resistance to one or multiple classes of antimicrobial agents (Chen et al., 2012).

Antimicrobial resistance in motile aeromonads of aquaculture environment The intensive use of antimicrobials in aquaculture to combat diseases provides a selective pressure creating reservoirs 
of drug-resistant bacteria and transferable resistance genes in fish pathogens and other bacteria in the aquatic environment (Romero et al., 2012). Various authors have emphasized the putative negative effects of using antimicrobial agents in fish farms (Romero et al., 2012; Watts et al., 2017; Aich et al., 2018). Motile aeromonads remain the most dominant group isolated from aquatic environments due to its omnipresence. The major studies dealing with the general susceptibility of motile aeromonads of fish to various classes and combinations of antimicrobial agents are very limited. Susceptibility patterns of Aeromonas spp. from aquatic environments to various antimicrobial agents are well documented (Romero et al., 2012). Aeromonas hydrophila strains resistant to third and fourth generations cephalosporins, aminoglycosides, quinolone and fluoroquinolones and other commonly used antibiotics, and sensitive to cephalosporins (cefuroxime, ceftriaxone, cefpodoxime, cefalotin, ceftazidime, cephalexin, cefoxitin, cefotaxime), chloramphenicol, tetracycline, imipenem, quinolones, gentamicin, kanamycin, nitrofurantoin, norfloxacin, streptomycin, sulphamethoxazole, ciprofloxacin, oxytetracycline, doxycycline, amikacin, aminoglycosides, amoxicillin, ticarcillin, ofloxacin, pefloxacin, neomycin, oxacillin, gatifloxacin and levofloxacin have been isolated from different diseased fish in different parts of world (Kaskhedikar and Chhabra, 2010; Ashiru et al., 2011; Aravena-Román et al., 2012; Romero et al., 2012; Afizi et al., 2013; Samal et al., 2014; Wamala et al., 2018). Few studies reported the susceptibility data for Aeromonas species other than A. hydrophila, A. caviae, and $A$. veronii bv. sobria (Zhou et al., 2019). Several other studies have shown a high prevalence of drug-resistant Aeromonas spp. from fish (Č́́žek et al., 2010; Bardhan, 2019). Antibiotic-resistance profile of $A$. veronii, A. media, A. jandaei, A. hydrophila, A. caviae, A. culicicola and A. aquariorum isolated from the skin of ornamental fish imported to Portugal revealed a resistance level of $>80 \%$ to tetracycline, ticarcillin, carbenicillin, ampicillin and erythromycin. Ciprofloxacin and norfloxacin resistance was $43 \%$ and $34 \%$, respectively among A. hydrophila (Dias et al., 2012). Aeromonas schubertii isolated from diseased snakeheads in China was susceptible to cefoxitin and cefoperazone and resistant to policyclin, cefotamine, penicillin-G, clindamycin and oxacillin (Chen et al., 2012).

Paul et al. (2015) documented antibioticresistant motile aeromonads induced septicemia in catfish. Aeromonas spp. of diseased catfish were resistant to broadspectrum co-trimoxazole, chloramphenicol, ciprofloxacin, gatifloxacin, gentamicin, sulphafurazole and oxytetracycline. The results of Bardhan (2019) demonstrated that motile Aeromonas spp. of the carp aquaculture systems of West Bengal were highly resistant to amoxyclav (77.69\%), cefalexin (76.86\%) and nitrofurantoin $(67.88 \%)$. Considerably lower resistance to ciprofloxacin and sulfafurazole was noted. The multiple antibiotic-resistance (MAR) index of these motile aeromonad strains varied between 0.33 and 1.0 (Bardhan, 2019). The uprise in AMR among these motile aeromonads suggested a heavy uproar and concern. These observations are of great concern because a sample with MAR index above 0.2 is considered to be exceedingly manifested with antibiotics and having a high-risk factor (Saka et al., 2017). The results of several earlier studies also 


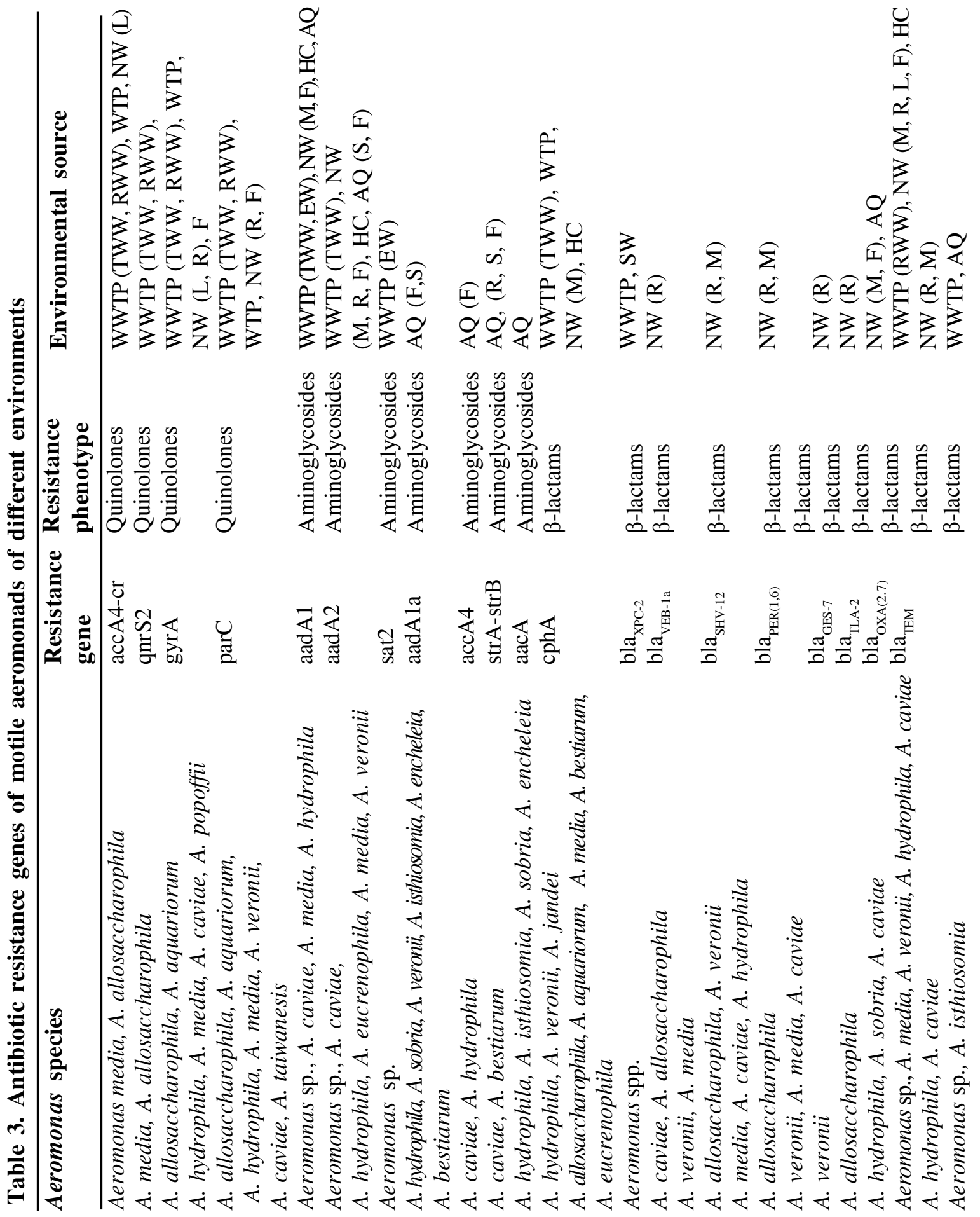




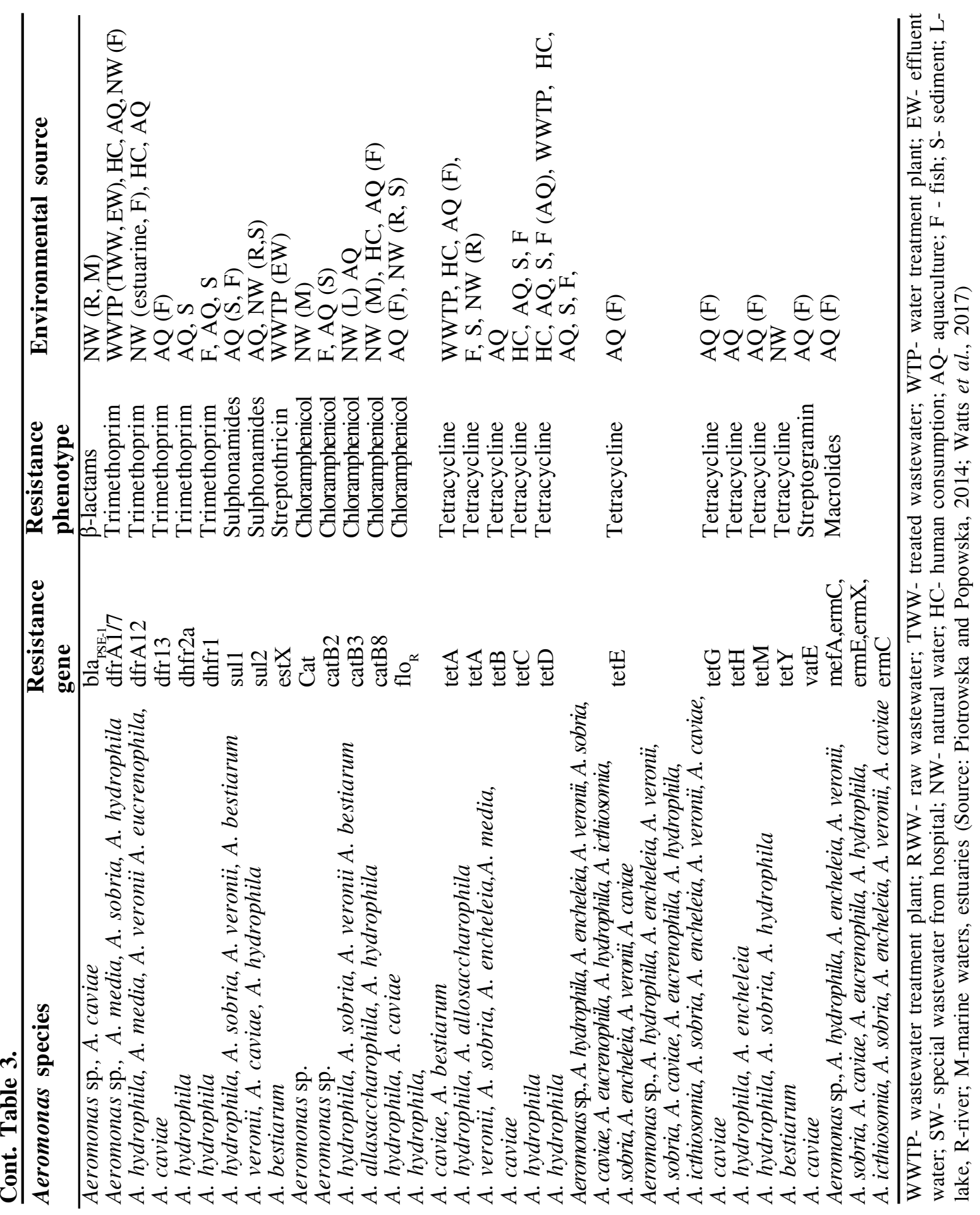


suggested the role of aeromonads as reservoirs or vectors of antimicrobial resistance determinants through horizontal gene transfer between aeromonads and coexistent bacteria in aquatic or gut microenvironments (Sreedharan et al., 2012; Bharathkumar and Abraham, 2013). The MAR Aeromonas spp. found in different cultured freshwater fish implied that difficulties might arise in the prophylaxis and therapy of Aeromonas infections (Romero et al., 2012; Bharathkumar and Abraham, 2013; Bardhan, 2019). The recent trends of AMR among motile aeromonads and other bacteria isolated from fish demonstrated the abuse of antibiotics (Romero et al., 2012; Watts et al., 2017; Bardhan, 2019). Such trends of AMR among the most dominant bacterial flora of the aquatic environment indicated a danger to humans and animals as well (Watts et al., 2017).

\section{Antibiotic-resistant genes (ARGs) in motile aeromonads}

Antimicrobial resistance in bacterial populations can occur from the clonal selection under antimicrobial selective pressure or through horizontal gene transfer. Mobile genetic elements viz., plasmids, integrons and transposons contribute to wider dissemination of genetic resistance determinants among bacterial populations (Piotrowska and Popowska, 2015). The Tn3 family of transposons play a central role in disseminating resistance to antibiotics in Gram-negative bacteria such as Aeromonas (Carnelli et al., 2017). They are especially associated with MAR plasmids of Aeromonas (del Castillo et al., 2013). Genetic determinants such as integrons, transposons and resistance plasmids, involved in the spread of antibiotic resistance, were often detected in Aeromonas strains and may be a crucial genotypic determinant for AMR among motile aeromonads (Carnelli et al., 2017). Aeromonas spp. are the part of the bacterial population with several chromosomal $\beta$ lactamase genes, including $c p h A, c e p H$ and $a m p H$, which encode class $\mathrm{B}, \mathrm{C}$ and $\mathrm{D} \beta$ lactamases, respectively (Balsalobre et al., 2010). Integrons-inserted gene cassettes have been documented in widespread Aeromonas species isolated from diseased fish (Piotrowska and Popowska, 2014). The most often found resistance gene cassettes contained several aminoglycoside resistance genes aadA1, aadA2, and the trimethoprim resistance gene $d f r A l$ (Piotrowska and Popowska, 2015). Aeromonas spp. isolated from natural waters frequently demonstrated a tetracycline-resistance phenotype (Tacão etal., 2012). The resistance to oxytetracycline was most often coded by the tet(E) gene or by a combination of the tet (E) gene with tet (A) and tet (D) genes in motile aeromonads from common carp and koi carp (Čížek et al., 2010). A wide range of antibiotic-resistance genes (ARGs) have been documented in motile aeromonads from different environments and the details of the same are presented in Table 3. The prevalence of several of these genes suggested that motile Aeromonas spp. can be unique vectors in spreading the ARGs in the aquatic environment.

\section{Mitigation}

The last decade of the $20^{\text {th }}$ century and the first decade of the $21^{\text {st }}$ century have witnessed the emergence and spread of 
antibiotic resistance in pathogenic bacteria around the World, and the consequent failure of antibiotic therapy (Palmer and Kishony, 2013). Aeromonas hydrophila was reportedly caused lung colonization with cystic fibrosis, believed to have originated from the tropical fish tank (Cremonesini and Thomson, 2008) and zoonotic via spine puncture or open wounds (Haenen et al., 2013). Although no cases of resistant motile aeromonad infections that has been transferred from fish to humans are available, it has been speculated that transmission to humans may occur when cultured fish containing AMR bacteria and ARGs are consumed. Therefore, to address the problem of antibiotic-resistance, effective strategies are required. As global production of aquatic species (fish, shellfish, shrimp and molluscs) has been growing rapidly in the last decade, the use of antibiotics in aquaculture also increased (Watts et al., 2017). To prevent the emergence and transfer of antibiotic resistance in aquatic food animals, new methods to manage infectious diseases in aquaculture are required. For example, optimal use of existing vaccines can be a viable alternative (Assefa and Abunna, 2018). Improving hygiene (Austin and Austin, 2016), using enzymes, probiotics, prebiotics and acids to improve health (Sayes et al., 2018; Hoseinifar et al., 2018), and utilizing bacteriocins, antimicrobial peptides and bacteriophages as substitutes for antibiotics might be good methods to promote fish growth and decrease infectious diseases in them (Rao and Lalitha, 2015).

The Study for Monitoring Antimicrobial Resistance Trends (SMART) is the premier global surveillance system on antimicrobial resistance of microbes since 2002. It is a global surveillance program designed to longitudinally monitor the epidemiological trends and in vitro antimicrobial susceptibilities of 12 antimicrobial agents against a variety of aerobic and facultative Gram-negative bacilli isolated from patients with intra-abdominal infections (Hsueh, 2012). Data from SMART studies showed that the level of antimicrobial resistance differs by geographic region and is highest in Asia-Pacific countries (Sumpradit et al., 2017). Likewise, it is worthwhile to formulate internationally acceptable standard protocols about the use of antibiotics in aquaculture and about surveillance programs to monitor the global emergence of MAR bacteria. Reducing antibiotic use in aquaculture is also important. Policies to change the use of antibiotics in aquaculture can include ban or restriction on using medically important antibiotics, promising financial incentives for developing aquatic animal-specific antibiotics, making drug licensing rules more stringent and imposing penalties on defaulters. Continuous efforts to educate people about antibiotic resistance are a very important strategy. Improvement of sanitation and hygiene in aquaculture is also meaningful (Romero et al., 2012; Stratev and Odeyemi, 2017). As the major suitable targets of antibiotics have already been identified, to discover new classes of antibiotics, novel strategies for rational design and screening-based approaches are required. Unlike conventional antimicrobial drugs, new strategies are also presented for the treatment of microbial diseases, such as host defence peptides, bacteriophages, 
vaccines, immunoglobulins, and probiotics (Lloyd, 2012). Future prospects for MAS control include the development of a modified-live vaccine as well as a vaccine against the various enzymes and toxins produced by Aeromonas spp. (Stratev and Odeyemi, 2017).

\section{Conclusion}

The tenacity and propagation of AMR in the environment represent a global health crisis. According to FAO/OIE/WHO (2019), if AMR is not controlled or monitored, we will be moving to a post-antibiotic era, an era where no new antibiotics replacement will be available and common, simple, treatable diseases would lead to a new epidemic. Therefore, it is critical that we understand environmental hotspots for genetic exchange of AMR genes such as aquaculture systems and determine how they might transfer to clinically equivalent strains. In general, infections caused by Aeromonas spp. do not directly pose a substantial threat to public health. However, the transfer of ARGs causes ineffectiveness of antibiotic treatment

\section{REFERENCES}

Afizi MK, Fatimah BS, Mariana NS and Abdel-Hadi YM, 2013. Herbal and antibiotic resistance of Aeromonas bacteria isolated from cultured fish in Egypt and Malaysia. J Fish Aquat Sci, 8(2): 425-429

Aich N, Ahmed N and Paul A, 2018. Issues of antibiotic resistance in aquaculture industry and its way forward. Int J Curr Microbiol Appl Sci, 7(8): 26-41 of fish diseases and leads to significant economic losses in aquaculture. Given the role of Aeromonas spp. as ARG vectors between environmental bacteria and clinical human pathogens, as well as the existence of MAR Aeromonas strains, and the location of ARG on mobile genetic elements, the presence of resistant Aeromonas strains in the environment may pose a serious threat to human health. The alternative disease management strategies combined with a better understanding of the effects on the microbiome of the farmed fish may provide alternative solutions to improve aquaculture health and function while reducing the potential for the spread of antimicrobial resistance.

\section{ACKNOWLEDGEMENT}

Authors are thankful for the support to the Indian Council of Agricultural Research, Government of India, New Delhi under All India Network Project on Fish Health and the Vice-Chancellor, West Bengal University of Animal and Fishery Sciences, Kolkata for providing necessary infrastructure facilities of the laboratory.

Aravena-Román M, Inglis TJ, Henderson B, Riley TV and Chang BJ, 2012. Antimicrobial susceptibilities of Aeromonas strains isolated from clinical and environmental sources to 26 antimicrobial agents. Antimicrob Agents Chemother, 56(2): 1110-1112

Ashiru AW, Uaboi-Egbeni PO, Oguntowo JE and Idika CN, 2011. Isolation and antibiotic profile of Aeromonas species from tilapia fish 
(Tilapia nilotica) and catfish (Clarias batrachus). Pak J Nutr, 10(10): 982-986

Assefa A and Abunna F, 2018. Maintenance of fish health in aquaculture: review of epidemiological approaches for prevention and control of infectious disease of fish. Vet Med Int, 2018: 10

Austin B and Austin DA, 2016. Aeromonadaceae representatives (motile aeromonads). In Bacterial Fish Pathogens. Springer, Cham (Switzerland), pp161-214

Balsalobre LC, Dropa M, de Oliveira DE, Lincopan N, Mamizuka EM et al., 2010. Presence of blaTEM-116 gene in environmental isolates of Aeromonas hydrophila and Aeromonas jandaei from Brazil. Braz J Microbiol, 41(3): 718-719

Bardhan A, 2019. Surveillance of antibiotic resistance in motile Aeromonas spp. from freshwater aquacultured fish. M.F.Sc thesis. West Bengal University of Animal and Fishery Sciences, Kolkata, India

Bharathkumar G and Abraham TJ, 2013. Prevalence of transferable oxytetracycline resistance factors in Aeromonas hydrophila in fish hatcheries. Fish Technol, 50: 324-330

Beaz-Hidalgo R, Martínez-Murcia A and Figueras MJ, 2013. Reclassification of Aeromonas hydrophila subsp. dhakensis (Huys et al., 2002) and Aeromonas aquariorum (Martínez-Murcia et al., 2008) as Aeromonas dhakensis sp. nov. comb nov. and emendation of the species Aeromonas hydrophila. Syst Appl Microbiol, 36: 171176

Carnelli A, Mauri F and Demarta A, 2017. Characterization of genetic determinants involved in antibiotic resistance in Aeromonas spp. and faecal coliforms isolated from different aquatic environments. Res Microbiol, 168(5): 461471

Chen PL, Ko WC and Wu CJ, 2012. Complexity of $\beta$-lactamases among clinical Aeromonas isolates and its clinical implications. J Microbiol Immunol Infect, 45(6): 398-403

Čížek A, Dolejská M, Sochorová R, Strachotová K, Piačková V et al., 2010. Antimicrobial resistance and its genetic determinants in aeromonads isolated in ornamental (koi) carp (Cyprinus carpio koi) and common carp (Cyprinus carpio). Vet Microbiol, 142(3-4): 435-439

Cremonesini D and Thomson A, 2008. Lung colonization with Aeromonas hydrophila in cystic fibrosis believed to have come from a tropical fish tank. J R Soc Med, 101(1_suppl): 44-45

del Castillo CS, Hikima JI, Jang HB, Nho SW, Jung TS et al., 2013. Comparative sequence analysis of a multidrug-resistant plasmid from Aeromonas hydrophila. Antimicrob Agents Chemother, 57(1): 120-129

Deng Y, Wu Y, Jiang L, Tan A, Zhang R et al., 2016. Multi-drug resistance mediated by class 1 integrons in Aeromonas isolated from farmed freshwater animals. Front Microbiol, 7: 935

Dias C, Mota V, Martinez-Murcia A and Saavedra MJ, 2012. Antimicrobial resistance patterns of Aeromonas spp. isolated from ornamental fish. J Aquacult Res Dev, 3(3): 131

FAO/OIE/WHO, 2019. Food and Agriculture Organisation/Office International des Epizooties/World Health Organisation. Publication on monitoring and evaluation of 
the global action plan on antimicrobial resistance: Framework and recommended indicators, FAO, Rome

Graf J, 2015. Aeromonas. Caister Academic Press, Norfolk (UK)

Gutsell JS, 1946. Sulfa drugs and the treatment of furunculosis in trout. Science, 104(2691): 8586

Haenen OL, Evans JJ and Berthe F, 2013. Bacterial infections from aquatic species: potential for and prevention of contact zoonoses. Rev Sci Tech OIE, 32(2): 497-507

Hanson L, Liles MR, Hossain MJ, Griffin M and Hemstreet W, 2014. Motile Aeromonas septicemia. In Fish Health Section Blue Book edn., 2014, Section1. 2.9. American Fisheries Society-Fish Health Section. Bethesda, Maryland

Hoseinifar SH, Sun Y, Wang A and Zhou Z, 2018. Probiotics as means of diseases control in aquaculture, a review of current knowledge and future perspectives. Front Microbiol, 9: 2429

Hsueh PR, 2012. Study for monitoring antimicrobial resistance trends (SMART) in the Asia-Pacific region, 2002-2010. Int J Antimicrob Agents, 40: S1

Janda JM and Abbott SL, 2010. The genus Aeromonas: taxonomy, pathogenicity, and infection. Clin Microbiol Rev, 23(1): 35-73

Kaskhedikar M and Chhabra D, 2010. Multiple drug resistance in Aeromonas hydrophila isolates of fish. Food Microbiol, 28: 157-168

Kimura M, Araoka H and Yoneyama A, 2013. Aeromonas caviae is the most frequent pathogen amongst cases of Aeromonas bacteremia in Japan. Scand J Inf Dis, 45(4): 304-309
Králová S, Staňková E and Sedláček I, 2016. Classification of Aeromonas spp. isolated from water and clinical sources and distribution of virulence genes. Folia Microbiol, 61(6): 513-521

Leonard AF, Zhang L, Balfour AJ, Garside R and Gaze WH, 2015. Human recreational exposure to antibiotic-resistant bacteria in coastal bathing waters. Environ Int, 82: 92-100

Li W, Shi Y, Gao L, Liu J and Cai Y, 2012. Occurrence of antibiotics in water, sediments, aquatic plants, and animals from Baiyangdian Lake in North China. Chemosphere, 89(11): 1307-1315

Lloyd DH, 2012. Alternatives to conventional antimicrobial drugs: a review of future prospects. Vet Dermatol, 23(4): 299-304, e59-60

Öztürk RÇ and Altınok İ, 2014. Bacterial and viral fish diseases in Turkey. Turk J Fish Aquat Sci, 14(1): 275-297

Palmer AC and Kishony R, 2013. Understanding, predicting and manipulating the genotypic evolution of antibiotic resistance. Nat Rev Genet, 14(4): 243

Paul P, Adikesavalu H, Banerjee S and Abraham TJ, 2015. Antibiotic-resistant motile aeromonads induced septicemia in Philippine catfish Clarias batrachus (L) fingerlings. Croatian J Fish, 73(4): 170-175

Piotrowska M and Popowska M, 2014. The prevalence of antibiotic resistance genes among Aeromonas species in aquatic environments. Ann Microbiol, 64(3): 921934

Piotrowska M and Popowska M, 2015. Insight into the mobilome of Aeromonas strains. Front Microbiol, 6: 494 
Plumb JA, 2018. Health maintenance of cultured fishes: Principal Microbial Diseases. CRC Press (US)

Rao BM and Lalitha KV, 2015. Bacteriophages for aquaculture: Are they beneficial or inimical. Aquaculture, 437: 146-154

Rasmussen-Ivey CR, Figueras MJ, McGarey D and Liles MR, 2016. Virulence factors of Aeromonas hydrophila in the wake of reclassification. Front Microbiol, 7: 1337

Romero J, Feijoó CG and Navarrete P, 2012. Antibiotics in aquaculture-use, abuse and alternatives. Health and environment in aquaculture. IntechOpen. Available at: https:/ /www.intechopen. com/books/health-andenvironment-in-aquaculture/antibiotics-inaquaculture-use-abuse-and-alternatives

Saka BA, Adeyemo OK and Odeseye AO, 2017. Multiple antibiotic resistance indices of Aeromonas hydrophila isolates of the muscle of catfish (Clarias gariepinus, Burchell 1822) from selected markets in Ibadan, Nigeria. African J Clin Exp Microbiol, 18(2): 73-78

Samal SK, Das BK and Pal BB, 2014. Isolation, biochemical characterization, antibiotic susceptibility study of Aeromonas hydrophila isolated from freshwater fish. Int J Curr Microbiol Appl Sci, 3(12): 259-267

Sayes C, Leyton Y and Riquelme C, 2018. Probiotic bacteria as a healthy alternative for fish aquaculture. Antibiotic use in animals. Intech Open, London: 115-132. Available at: https:/ /www.intechopen.com/books/antibiotic-usein-animals/probiotic-bacteria-as-an-healthyalternative-for-fish-aquaculture

Schäperclaus W, 1930. Pseudomonas punctata als Krankheitserreger bei Fischen. Zeitung für
Fischerei, 28: 289-370 (In German)

Sreedharan K, Philip R and Bright Singh IS, 2012. Virulence potential and antibiotic susceptibility pattern of motile aeromonads associated with freshwater ornamental fish culture systems: A possible threat to public health. Braz J Microbiol, 43(2): 754-765

Stratev D, Stoev S, Vashin I and Daskalov H, 2015. Some varieties of pathological changes in experimental infection of carps (Cyprinus carpio) with Aeromonas hydrophila. J Aqua Eng Fish Res, 1(4): 191-202

Stratev D and Odeyemi OA, 2016. Antimicrobial resistance of Aeromonas hydrophila isolated from different food sources: A mini-review. J Infect Public Health, 9(5): 535-44

Stratev D and Odeyemi OA, 2017. An overview of motile Aeromonas septicaemia management. Aquacult Int, 25(3): 1095-1105

Sumpradit N, Wongkongkathep S and Poonpolsup $S, 2017$. A new chapter in addressing antimicrobial resistance in Thailand. Brit Med J, 358: 3415

Tacão M, Correia A and Henriques I, 2012. Resistance to broad-spectrum antibiotics in aquatic systems: anthropogenic activities modulate the dissemination of bla ${ }_{\text {Стх-м }}$-like genes. Appl Environ Microbiol, 78(12): 4134-4140

USFWS, 2015. Approved Drugs for Use in Aquaculture. Second edn., U.S. Fish and Wildlife Service's Aquatic Animal Drug Approval Partnership Program, American Fisheries Society's Fish Culture and Fish Health Sections, Association of Fish and Wildlife Agencies, and Fisheries and Water Resources Policy Committee's Drug Approval Working Group 
Wamala SP, Mugimba KK, Dubey S, Takele A, Munangandu HM et al., 2018. Multilocus sequence analysis revealed a high genotypic diversity of Aeromonas hydrophila infecting fish in Uganda. J Fish Dis, 41(10): 1589-1600

Watts JE, Schreier HJ, Lanska L and Hale MS, 2017. The rising tide of antimicrobial resistance in aquaculture: sources, sinks and solutions. Mar Drugs, 15(6): 158
Zhou Y, Yu L, Nan Z, Zhang P, Kan B et al., 2019. Taxonomy, virulence genes and antimicrobial resistance of Aeromonas isolated from extra-intestinal and intestinal infections. BMC Infect Dis, 19(1): 158

Zimmerman OER, 1890. Die Bakterien unserer Trink-und Nutzwassers, part 1. Ber Naturw Ges Chemnits pp38-39 (in German)

Article received on 21.10.2019 and accepted for publication on 20.11.2019 